Quang Hung Nguyen, Nikolay N. Kosarenko, Elmira R. Khairullina in Olga V. Popova

\title{
The Relationship between the State and the Catho- lic Church in Postcolonial Vietnam: The Case of Christian Village of Phung Khoang
}

\section{Odnos med državo in katoliško Cerkvijo v postkoloni- alnem Vietnamu: krščanska vas Phung Khoang}

Abstract: Christian missionaries found Vietnam a spiritual country, and many Vietnamese converted to Christianity. On the other hand, during history, the Christian religious identity has brought various tensions due to the issues of colonialism, nationalism, and communism. Most Vietnamese Christians lived in pure Christian villages (lang cong giao toan tong) or mixed villages with Christians accounting for about a half of the population (lang cong giao xoi do). They have played an important role in the social, economic and cultural life of these villages. This article presents the historical background of a mixed village called Phung Khoang, contrasting the Christian vs. non-Christian cultural-religious views, and then discussing both the collaboration and tension played out over various historical periods.

Key words: Phung Khoang, Christianity, Vietnamese Catholic Christians, Christian missionaries

Povæ̌etek: Krščanski misijonarji so Vietnam doživljali kot duhovno dovzetno deželo in veliko Vietnamcev se je spreobrnilo v krščanstvo. Po drugi strani je krščanska verska istovetnost - zaradi kolonializma, nacionalizma in komunizma - skozi zgodovino povzročala različne napetosti. Večina vietnamskih kristjanov je živelo v povsem krščanskih vaseh (lang cong giao toan tong) ali mešanih vaseh, v katerih so kristjani sestavljali približno polovico prebivalcev (lang cong giao xoi do). Kristjani so igrali pomembno vlogo $v$ družbenem, $v$ gospodarskem in v kulturnem življenju teh vasi. Članek prikazuje zgodovinsko ozadje mešane vasi Phung Khoang, pri tem se posveča primerjavi med krščanskimi in nekrščanskimi kulturno-verskimi nazori, nato pa razpravlja tako o sodelovanju kakor tudi o napetostih, ki so se dogajale v različnih zgodovinskih obdobjih.

Ključne besede: Phung Khoang, krščanstvo, vietnamski katoliški kristjani, krščanski misijonarji 


\section{Introduction: historical background of Phung Khoang}

Phung Khoang, formerly known as Khoang Village or Phung Quang, is an old Christian village founded in the $16 / 17^{\text {th }}$ century during the Le dynasty (Ngo 1975, 71). In the $19^{\text {th }}$ century, the village was renamed Phung Khoang and belonged to Dai Mo, Quoc Oai Prefecture, Son Tay Province. At the beginning of the $20^{\text {th }}$ century, it became part of Ha Dong Province. Today Phung Khoang is one of two villages of the Trung Van co-operative commune, in the Tu Liem District. It is less than ten miles south of the center of Hanoi and just two miles from Ha Dong City. Its territory is about 120 hectares (almost 300 acres) with a population of about 2.100, including 1.064 Christians in 2005. ${ }^{1}$ These Christians make up two-thirds of the Phung Khoang Parish, which has a total of 1.850 Christians in 1995.

Traditionally Phung Khoang was an agricultural village, as people said, "Tien lang Moc, thoc lang Khoang" (Moc Village was known for having money and Phung Khoang Village for rice). Only since the 1990's there have been radical changes in village life. On the one hand, there are social-economical transformations. Two-thirds of the living earning of native villagers are from occupations other than agriculture, such as handicraft industries and services. The living standard has improved. Per capita personal income is now 700 USD. ${ }^{2}$ Phung Khoang is not poor and its cultural standard (dan tri) is relatively high. Some families have three or four children studying in a university or an institute, ${ }^{3}$ and most families have telephones, TV, mopeds, and other modern means.

Phung Khoang is also being urbanized and may no longer remain a village in two decades. ${ }^{4}$ It is overpopulated and polluted. About 4.000 students of the universities of architecture, Post and Telegraph, and Vietnam National University live in Phung Khoang now. About $90 \%$ of families have rooms for rent. This unplanned "student village" brings many social evils such as prostitution, gambling, and drug (mostly spread by non-native residents).

Phung Khoang is culturally and spiritually rich. The village's communal house (dinh) was built in the $17^{\text {th }}$ century. People revere the village's tutelary genie (thanh hoang lang) Doan Thuong, an army general in the $13^{\text {th }}$ century. ${ }^{5}$ There are six stone steles (van bia) in the village's communal house, of which the oldest was built in 1698 . Vestiges of the Le dynasty can be seen in the village's communal house. There were eight honors (sac phong) of kings of the Le and the Nguyen dynasties for the village's tutelary genie. ${ }^{6}$ Old parallel sentences (cau doi) about Doan Thuong in his struggle to save the Ly dynasty in its declined period are still hanging in the communal house.

1 The Christian population included 517 men and 547 women, all Catholics.

2 In comparison, the US per capita personal income in 2007 is 38.611 , or more than 50 times, according to the US Department of Commerce: http://www.bea.gov/regional/spi/drill.cfm (2008).

3 Sixty-nine people finished their studies at a university or institute in 1995-2005.

4 The same situation is in other villages in suburbs Hanoi, such as Co Nhue.

5 Doan Thuong had built his troops against the Tran family. He was killed by Tran Thu Do's troops in a battle in Hai Duong. He is reportedly venerated in 72 villages.

6 The first honor was by king Canh Hung in 1783, the second, Minh Mang in 1821, the third, Thieu Tri in 
The present pagoda in Phung Khoang, Thanh Xuan Tu, was re-built in 1877. Formerly it was a temple for a Trinh family in the $17^{\text {th }}$ century. ${ }^{7}$ A stone stele in this temple dated back to 1692. In the following century, it was transformed into a pagoda. Both the village's communal house and the pagoda were repaired and recognized by the Culture Department of Hanoi in 1991 as historical vestiges (di tich lich su). The village festival is carried out yearly on January $8^{\text {th }}$ of the lunar calendar, recently restored in the last two decades. Every five years people celebrate a festival of the Moc Village, which was founded in the $11^{\text {th }}$ century, the predecessor of Phung Khoang and its four neighboring villages. The historical context shows the dichotomies between Christians and non-Christians, between native villagers and non-native residents. Next, we will contrast the Christian and non-Christian views. ${ }^{8}$

\section{Christian and non-Christian cultural-religious views}

The first groups of Christian missionaries, headed by Alexandre de Rhodes, might have reached Phung Khoang because of its proximity to the Thang Long capital. There were sixteen churches in the capital and its suburbs before the arrival of the Missions Etrangères de Paris (MEP) in the second half of the $17^{\text {th }}$ century (Nguyen 1959, 226). Then Phung Khoang Christians suffered persecution under the emperors Minh Mang and Tu Duc. ${ }^{9}$ Therefore, the Christian parish of Phung Khoang was not founded until the end of the $19^{\text {th }}$ century. The present parish church was built in $1910 .{ }^{10}$ The Phung Khoang parish flourished in the colonial period and had 1.689 Christians by 1939 (Truong 1996, 153).

From a cultural-religious point of view, Christians and non-Christians here remained relatively independent from each other, as displayed in the following table:

\begin{tabular}{|l|l|}
\hline Traditional non-Christians & Christians \\
\hline $\begin{array}{l}\text { Under the influences of the traditional East Asian } \\
\text { Confucian culture. }\end{array}$ & $\begin{array}{l}\text { Under the influences of the Christian-European } \\
\text { culture. }\end{array}$ \\
\hline Loyal to the emperor (trung quan) above all. & Loyal to the emperor, but Christ comes first. \\
\hline $\begin{array}{l}\text { Patriarchy: the male conducted ancestor veneration } \\
\text { and inherited property. }\end{array}$ & $\begin{array}{l}\text { Gender equality: women are emancipated; mo- } \\
\text { nogamy. }\end{array}$ \\
\hline
\end{tabular}

1844 , the fourth, Tu Duc in 1850 , the fifth, Tu Duc in 1881, the sixth, Dong Khanh in 1887, the seventh, Duy Tan, and the eight, Khai Dinh in 1924.

7 In this temple a discussion of the Trinh family in 1623 was held about the succession of the throne of Trinh Tung in the context of the conflict between his first son and second son. Trinh Trang was allowed to succeed the throne.

8 The authors of this article built on the results of an extensive field research, the partial findings of which were published in: Nguyen 2008a, 13-25.

9 Tonkin under the governor Nguyen Dang Giai (in the middle of the $19^{\text {th }}$ century) usually did not obey the anti-Christian edicts of Emperor Tu Duc. For example, the harsh anti-Christian edict in 1851 was not carried out by both governors Nguyen Dang Giai in Tonkin and Nguyen Tri Phuong in Cochinchina.

10 The first church in Phung Khoang was built under Tu Duc, but it was small and destroyed. 


\begin{tabular}{|l|l|}
\hline Parents-children: piety with ancestor veneration. & $\begin{array}{l}\text { Parents-children: piety, but without ancestor } \\
\text { veneration }{ }^{11}\end{array}$ \\
\hline $\begin{array}{l}\text { Cultural-religious life: polytheism, not devout to any } \\
\text { religion. }\end{array}$ & Cultural-religious life: monotheism, devout. \\
\hline Religiously inclusive and tolerant. & Religiously exclusive. \\
\hline $\begin{array}{l}\text { Religious activities: private, without ecclesiastical } \\
\text { organization. }\end{array}$ & $\begin{array}{l}\text { Religious activities: collective, with ecclesiastical } \\
\text { organization. }\end{array}$ \\
\hline Relationship with God: a relative distance. & Relationship with God: an absolute distance. \\
\hline Hierarchy: by age and social position. & Hierarchy: by ecclesiastical position. \\
\hline
\end{tabular}

There have been changes in both the Christian and non-Christian communities in the last few decades. The Second Vatican Council opened the Catholic Church up to other religions and cultures. Vietnamese Catholics can venerate ancestors. Nowadays the Catholic Church in Vietnam is very active in supporting a cultural integration. On the non-Christian side, in the context of the Renovation (Doi Moi) and the collapse of the Communist bloc in the former Soviet Union and Eastern Europe, Vietnam carried out a more open policy regarding religion with the Resolution Nr. 24 of CPV in November 1990. However, significant differences between Christians and non-Christians still exist. We will briefly examine the ritual differences.

The "ritual question" (van de nghi le) has not been systematically analyzed. It appeared in Vietnam since the beginning of the Christian mission. In the $19^{\text {th }}$ century, the issue became more serious because the Nguyen dynasty considered Confucianism the "state religion." In a Confucian state, the emperor has absolute power, which is not acceptable to Christians. If Vietnam became more Christian, the legitimacy of the emperor and his dynasty would be challenged - thus, the question about the ritual was also a political one.

Before this question was intensified, Christians and non-Christians in Phung Khoang coexisted peacefully and even collaborated well through several centuries. Non-Christians helped Christians build the parish church. On the three steles by the church, there are national writings (Quoc ngu), Nom and Chinese. ${ }^{12}$ Some Christians had non-Christian relatives, and they celebrated together on numerous occasions, such as death anniversaries and New Year (gio, Tet). Marriages between Christians and non-Christians were common.

There were differences even during those "good days." Before the Second Vatican Council, Catholics were not allowed to venerate their ancestors. Even now some Christians in Phung Khoang do not have an ancestor altar. They had another concept of piety (hieu thao) than Confucians. Non-Christians valued sons more than daughters, which was not true for Christians. Except for New Year (Tet) and Mid-Autumn Festival (Trung Thu), Christians did not participate in the village's traditional festivals such as the Nguyen Tieu on $15^{\text {th }}$ January, the Thanh Minh on

\footnotetext{
11 The Vietnamese Catholics were allowed to carry out their ancestor veneration only after the Second Vatican Council.

12 The oldest of those steles was built in 1893, the other was in 1913, and the last in 1927.
} 
$3^{\text {rd }}$ March, the Doan Ngo on $5^{\text {th }}$ May and the Vu Lan on $15^{\text {th }}$ July of the lunar calendar (Nguyen 2006, 22-23). ${ }^{13}$ The lunar calendar was not important for them. Instead, they celebrated Christian festivals such as Christmas and Easter. On Sundays, they went to church and did not work. Christian family parties were usually frugal.

Since the end of the $19^{\text {th }}$ century, with the formation of the Christian parish, Christians and non-Christians in Phung Khoang have lived in two separate quarters (xom, giap). Christians conduct weddings and funerals differently. Except for the first death anniversary (gio dau), Christians in Phung Khoang do not carry out other customary rituals, such as on the $49^{\text {th }}$ and $100^{\text {th }}$ day after the death. Unlike their non-Christian relatives, they do not exhume and move the remains of the deceased. They have a planned cemetery called the "Holy Garden" (Vuon thanh). Nearby is a cemetery for non-Christians. A Christian is responsible for the Holy Garden and a non-Christian cares for the other one. The Holy Garden has strict regulations and preferences so that not all Christian villagers are equal after they die. ${ }^{14}$

The long-time cultural-religious differences between Christians and non-Christians did not decline after 1945. Viet Minh's Marxist doctrine had a philosophical, cultural and religious outlook contrary to that of Christianity, somewhat similar to the situation under the Nguyen dynasty. The two words, "Christian" and "ordinary civilian" (luong dan), continued to be used in official statements, just like under the Nguyen dynasty.

The "ritual question" is understandable because of unavoidable differences between Christianity and the Vietnamese traditional religions and beliefs. It is an excuse to divide Christians and non-Christians, but alone it could not account for eventual hostilities between the two groups. There were collaborative periods which will be reviewed next.

\section{Collaborative periods before 1954}

In the colonial period young men in Phung Khoang were recruited to the French army, among them were many Christians. Some of them were sent to Europe during the First and Second World Wars. Those men received privileges. According to the village convention of Dai Mo, each man in Phung Khoang serving in the French army was allowed to own a mau and 5 sao of land. ${ }^{15}$ Many villagers were recruited to perform heavy handiwork for colonial authorities. They did not have to pay the land rent (Lich su cach mang xa Trung Van 2005, 17). In 1924, the parish church opened a primary school. Christian and non-Christian children could

\footnotetext{
13 The same findings were confirmed by a series of interviews conducted in 2008 (Nguyen 2008b).

14 This is discrimination among the Catholics in "Saint Garden," especially against the un-devout or pre-Communist Catholics.

15 A sao is $360 \mathrm{~m}^{2}$, a mau is $3600 \mathrm{~m}^{2}$.
} 
go to this school. The tuition was free. There were Christian and non-Christian teachers. People had freedom of religion. In general, there was no hostility between Christians and non-Christians during this colonial period, except for a dispute in 1934 concerning a religious shrine. ${ }^{16}$ The village communal house was a common cultural center for all. Village leaders and notables were both Christians and non-Christians. A Communist cell could not be established there until 1945 (34).

By the end of the colonial period, Phung Khoang was warm to welcome the Ho Chi Minh's government. ${ }^{17} \mathrm{~A}$ meeting in the village's communal house was held in 1945 (August $23^{\text {rd }}$ ) to welcome national independence. That year Phung Khoang suffered hunger, which killed 40 people, mostly non-Christians, including several complete families, but Phung Khoang collected fifteen tons of rice in a "gold week" for the Viet Minh (37). Communist cells and the Saving the Fatherland Groups (cuu quoc) were founded, with the participation of the Buddhist monks (38). Some young men who worked in a printing factory in Hanoi played a role in spreading the Communist propaganda. All villagers took part in the election of the First $\mathrm{Na}$ tional Assembly of DRV on January $6^{\text {th }}, 1946$. The Viet Minh founded the Administrative Resistance Committee of the Trung Van Commune (Uy ban Hanh chinh Khang chien xa Trung Van). In March 1946, Viet Minh clashed with the Chinese National troops in Phung Khoang after a Chinese soldier was killed there (42). Hundreds of men were mobilized into the patriotic movements against the French. Six young men joined a voluntary suicide squad. ${ }^{18}$ At the beginning of 1947 , Phung Khoang was under French occupation, and the local colonial authorities were restored as it was before 1945. At the beginning of the First Indochina War, part of the Buddhist pagoda was burned by a resistance fighter according to the scorched earth policy of Viet Minh (tieu tho khang chien). ${ }^{19}$

Deep in their hearts, Christians were nationalists. To cooperate with the French was not their motivation. J. Buttinger was right when he wrote: "To defeat the French and achieve national independence was an aim on which, with very few exceptions, all Vietnamese agreed; even those who hated the Viet Minh could not but sympathize with this cause." $(1958,11)$ Some Christians in Phung Khoang worked together with the resistance fighters against the French. There were Christians among the seventeen men who sacrificed their lives for the country (liet si) during the First Indochina War. ${ }^{20}$

16 Village's communal house in Phung Khoang is near to the church. In 1934, the parish priest in Phung Khoang planned to build a shrine to the Blessed Virgin Mary. Non-Catholics protested strongly against this plan because it faced the village's communal house. The dispute ended after the parish dropped the plan.

17 Before 1945 Phung Khoang had belong to Ha Dong province.

18 Four of them were sacrificed in First Indochina War.

19 Local Viet Minh had a plan to destroy the Church in Phung Khoang, but this plan was not carried out.

20 The mother of these Catholics who died for the country was recognized later as a hero because she had only one son left. 


\section{Conflicts after 1954}

\subsection{Exodus to South Vietnam}

Meanwhile, Christians feared the Communist Viet Minh. During the First Indochina War, most village officials and militia members were Christians. The parish priests in Phung Khoang actively co-operated with the French. More than thirty men (among them Christians and non-Christians) were recruited into postcolonial troops of Bao Dai's regime. A bunker was built there. Some native Communist guerrilla were disclosed and killed by their villagers. Many villagers who worked for Viet Minh were arrested and tortured in the First Indochina War. Although Bishop Joseph Maria Trinh Nhu Khue decided to remain in Hanoi with his believers, a priest, and more than three hundred Christians, about $40 \%$ of Christian population in the village of Phung Khoang at that time, left their homes for South Vietnam after the Geneva Agreement in 1954 (Lich su cach mang xa Trung Van $2005,57,60-61) .{ }^{21}$ In comparison, only $9 \%$ of the Christian population in Hanoi diocese left home.

\subsection{Land Reform}

After 1954, Phung Khoang was a "problematic Christian village" in the eyes of the Communist cadres from the security point of view. It had to come through difficult years of land reform.

"The DRV had an official policy of freedom of worship. However, even when local officials obeyed this policy (which they often did not), there was conflict. Catholicism was not simply a religious institution; it was a system of political, economic, and paramilitary power. The Communists were not willing to let the Catholic Church retain large amounts of land or any strong influence over local administrations, much fewer local militias." (Moise 1983, 193)

Before the land reform, Phung Khoang had a relatively good land situation in comparison to other neighbor villages in the suburbs of Hanoi. It had 585 mau for only 1.123 men (1926), and each young man (xuat dinh) was allotted a sao. There were not many changes until 1954. By the beginning of the land reform, all worship places (church, pagoda) in Phung Khoang owned 28 mau. They rented land and received land rent, so they were pretty well to do. ${ }^{22}$

Two teams implemented land reform in Trung Van in January 1956. Overall, it was a repression. By the middle of 1956, all land of the landlords was confiscated and distributed to the poor peasants. All church and pagoda properties were liquidated. Two persons in Phung Khoang were classified as landlords. They owned 50

21 However, some villagers say that the number of Catholics who had gone to South Vietnam was higher.

22 The church in Phung Khoang owned 18 mau, while the church in the neighboring village Trung Van owned only 6 mau. The pagoda in Phung Khoang owned 10 mau, while the pagoda in Trung Van owned only 2 mau and 6 sao. 
mau, including 33 mau of ponds and lakes, which was less than $10 \%$ of the total land area in Phung Khoang at that time. They inherited their estate from their fathers and received land rent. These two landlords, both Christians, were executed (Lich su cach mang xa Trung Van 2005, 13). ${ }^{23}$

Without land, the church and pagoda could not support their religious activities. Among people, who were classified to the "extortion class" (giai cap boc lot), were also Communists who had fought the French. Some soldiers of VNA and guerrilla could not be freed from sentences. Many Communists or core cadres had to denounce their parents or relatives publicly. Without detail investigation, people accused some Communists of belonging to oppositional Vietnam's Nationalist Party (Viet Nam Quoc dan dang). Two hundred men in the Trung Van commune were considered working for the colonial authorities. Hundreds of people were in prison because they or their relatives had connections to the "exploiting class." All the property of two landlords was confiscated so that their relatives had a lot of difficulties to live. Many people who were chosen as core cadres (cot can) were illiterate.

After these serious errors, a "correction" (sua sai) was implemented. Many people were released from the prison and reinstated, among them some Christians. ${ }^{24}$ In many cases, their properties were returned. The parish church was allowed to own two mau, including ponds. The Buddhist pagoda was allowed to own $5.880 \mathrm{~m} 2$. Although land reform was denounced by the middle of 1957, until now Christians (as well as non-Christians) here cannot forget the land reform days. ${ }^{25}$ Some considered the land reform in North Vietnam a blood bath (Hoang 1964). That might be an exaggeration, but the brutal conflict was a reality.

\subsection{Coop Farming}

Since October 1959, Christian and non-Christian peasants in Phung Khoang were mobilized to establish a co-operative farm. The following year, $90 \%$ of the villagers had to join a lower-level coop farm (hop tac xa cap thap). Most Christian peasants had to take part in coop farm "voluntarily," although they did not want it. ${ }^{26}$ Only eight families did not join the coop farm, among them some Christians. In 1964, Phung Khoang became an upper-level co-operative farm. The agricultural production in the 1960s was poor. In 1964 Phung Khoang had a crop failure and had to call the help from capital authorities $-50 \%$ of the peasants wanted to leave the coop farm. It is ironic that the Communist cell in Phung Khoang was so proud that it admitted twenty new members in 1965 and lobbied the upper Com-

23 Many villagers reported that one of these landlords was Mr. Chanh Than. He was a speaker of the rural assembly, herbal doctor, who did not do anything bad, and received sympathy from his villagers.

24 Among those people who were sentenced by the land reform was also a Communist. He was mistakenly classified as a resistance of a landlord rank. After the land reform he became the Vice Chairman of district Hoai Duc.

25 Many Catholics had lost all hope on the policy of DRV toward religion and in that time (after the Geneva Agreement) they had felt that it was better for them to go to the South Vietnam.

26 The Catholic Church considers privately owned property as an inalienable human right that is contrary to the Marxist concepts. 
munist organization to award it "the Communist cell of four virtues" (Lich su cach mang xa Trung Van 2005, 73). In 1966-1967, Phung Khoang was under American bombardment. The Commune Administrative Committee was built by the church to avoid the bombs. In that time the coop Trung Van Commune donated $152 \mathrm{~kg}$ rice, $100 \mathrm{~kg}$ pork, and 178 VND to the army. Only one out of 74 members of the Communist cell in Phung Khoang was expelled, and six others were reprimanded. This might have been the biggest achievement of the co-operative movement in Phung Khoang before Vietnam's unification. (81-88)

Both the communal house and one part of the parish church were used for public works. The church was used as a school. The communal house was used for storage and a preschool with kindergarten. A total of 174 young men (7,36 \% the population; 40 in 1968 alone) joined the Vietnamese People's Army. Some families had three or four men in VPA. Forty-one persons received different honors of VPA. The agricultural production after 1975 was not better. The rice output of the Trung Van coop was at its best in 1985, but only achieved 469 tons or 4,5 tons per hectare. In short, the social-economic situation, as well as the cultural-spiritual life, in Phung Khoang until the end of the 1980s was catastrophic.

\section{State and Church as conflicting institutions at the village level}

Until now, most scholars have examined the relationship between the state and the Christian Church from the social-political and cultural-religious points of view. We will examine them as two different organizations at the village level.

Clearly, the Communist Party and the Christian Church are two disciplined and basically closed organizations (hoi kin) with different histories, philosophical outlooks, and ideologies. The state considers materialistic Marxist ideology as a "state doctrine." The Christian Church could not accept the Marxist conception of religion as an "opium for people." The Communist Party wants to build a paradise in this world and socialism is considered as its first phase, without a role for religion. Thus, the Christian peasants are caught between the authorities of the state and the Christian Church.

During the period between 1945-1986, the Christian peasants in Phung Khoang were in a very difficult situation between the two institutions. Bishop Francois Chaize (Thinh in Vietnamese) did not cooperate with the Viet Minh during the First Indochina War. Since 1950, the town was under the See of Bishop Joseph Maria Trinh Nhu Khue, who had no contact with the Hanoi regime after land reform. ${ }^{27}$ The relation between the DRV and the Christian Church in North Vietnam worsened after 1945. During the Vietnam War, there was no contact between the Christian Church in North Vietnam and the outside world, even with the Holy See.

27 Bishop Joseph Maria Trinh Nhu Khue refused to take part at the meeting in 1958 on the initiative of the Premier Pham Van Dong to look for a co-operation between the state and Catholic Church. 
The relation between the state and the Church at the village level was a gulf, similar to the postcolonial period. ${ }^{28}$ There was no contact between the Viet Minh guerilla and Phung Khoang parish during the First Indochina War. After 1954, all kinds of religious worships were officially not prevented, but they were restricted, and local authorities discriminated against Christians in Phung Khoang, as in the postcolonial period. ${ }^{29}$ Every religious activity, even a procession for the Blessed Virgin or for Christ (ruoc kieu), could only be on the parish ground and under the strict control of the capital authorities.

Vietnamese traditional religions and beliefs were in the same situation. The last village's festival was carried out in 1939, and they were restored only in the last two decades. The relation between the local authorities and the parish in the first years after the Geneva Agreement was worse, because of the power struggle between the state and the Church at the village level during the exodus and land reform. Land reform team denounced the priest in Phung Khoang parish Paul Tran Dinh Thuy publicly (dau to) by a core Christian woman (cot can), but she did not classify him to the landlord rank. ${ }^{30}$ He was isolated from Christian peasants and was in hunger. By mistake, the correction officer treated him lighter. He died in 1957 at the age of seventy. In the eyes of many Christians, his death was considered as an indirect consequence of the land reform.

After the land reform, the tense relationship between the local authorities and the parish did not improve. Christians lacked pastors after the exodus and many seminaries were closed, including the Saint Joseph Seminary in Hanoi. ${ }^{31}$ One priest said mass at various parishes and his travels were restricted, though not prevented. Sometimes there was no mass on feast days, even Christmas. ${ }^{32}$ The appointment of every priest and catechist had to be approved by the state. A catechist in Phung Khoang, Peter Nguyen Van Nghi (born in 1942), was ordained to the priesthood without permission because his curriculum vitae was "problematic" (co van de ly lich). As a result, he was under house arrest for nine years. Only at the beginning of 1990 he was sent to study at the Saint Joseph Seminary and was appointed officially in 1994.

Some points should be emphasized in the analysis of the relation between the local authorities and the parish. Firstly, it was very difficult for a Christian to become a member of the CPV. Although there was officially no religious discrimination by CPV, a Christian Communist, in fact, received no support, either from the

28 Catholics co-operating with Viet Minh during First Indochina war had to leave the Church.

29 The first discrimination between Catholics and non-Catholics was taking place under the Nguyen dynasty. Non-Catholics were classified as ordinary citizen (/uong dan), while Catholics were called people of the "wrong religion" (ta dao). Those words in official state documents and individual curriculum vitae were common until 1986.

30 Some villagers reported that she later became insane (maybe because of remorse).

31 The lack of priests is improved in the last decades. Saint Joseph Seminary in Hanoi is allowed to accept students every year.

32 Although the situation has somewhat improved after the Saint Joseph Seminary in Hanoi re-opened in 1982, there were only 33 priests in the Hanoi Diocese by 1995. See: Truong 1996, 151-152. 
Christian Church or the Communist organizations. Most Christians had no motivation to join the CPV. Between 1954-1975 four Christians joined the Communist cell in Phung Khoang. They were not practicing and received no support from the parish. ${ }^{33}$ After 1986, the situation improved slightly, but there are still few Christian Communists. Among fifty-six Communists in Phung Khoang in 2006, only four were Christian. Among seventeen secretaries of the Communist cell in Trung Van during 1945-1995, there was not a single Christian. ${ }^{34}$

Secondly, there were few Christians who had a good position in the local government. The appointment of local cadres is supposed to follow the policy structure (co cau) that mobilizes both Christians and non-Christians. However, there were few Christians in a leadership position in the local institutions such as the Commune Administrative Committee (Uy ban hanh chinh $x a$ ), the Ho Chi Minh's Working Youth Union (today the Ho Chi Minh's Communist Youth Union), etc. Among nineteen chairmen of the Commune Administrative Committee (Uy ban Hanh chinh $x a$ ) in Trung Van before 1986, there were no Christians, though Christians made up two-fifths of the total population of Trung Van. Among eight heads of the co-operative farm (Chu nhiem Hop tac $x a$ ) only two were Christians. ${ }^{35}$ Sometimes Christians serve as second in command (cap pho). The situation after the Renovation improved, but not radically better. Christians take part in the Church youth organizations and have no time for other organizations. Some Christians take part in the local social works and are appointed to the Fatherland Front (Mat tran To quoc), People's Committee (Hoi dong Nhan dan), People's Inspection Committee (Ban thanh tra Nhan dan), etc. ${ }^{36}$

Thirdly, before 1990 there was no contact between the local authorities and the parish to decide local common issues (for example, against social ills or building of new life). The activities of the parish committee (Ban hanh giao) in Phung Khoang were not prohibited, but limited and under control and investigations. Although the situation now is improved, there is no co-operation between them to decide common local issues. The relationship is diplomatic and symbolic. The representatives of the local authorities and the parish have to visit each other on some occasions (New Year, Christmas). The parish priest in Phung Khoang is not interested in a pro-governmental Catholic Solidarity Committee (Uy ban Doan ket Cong giao). He was sometimes invited by the local authorities to take part in a meeting of the Fatherland Front (Mat tran To quoc) or at similar events, but he only sends his representatives.

33 One Catholic wanted to join the Communist cell. He was a Deputy head of a co-operative farm. He had to deny that he was a Catholic, but he still could not join because his true curriculum vitae was discovered. Another Catholic name, Joseph Tran Quoc Cuong, is now the head of a co-operative farm Thong Nhat (Phung Khoang), but he has no motivation to join the Communist cell. Among a hundred of Communists in the Trung Van cell there are only seven Catholics. Those Catholics are often not practicing.

34 The situation in the village of Co Nhue (Tu Liem, Ha Noi) is the same. Among 780 Communists there, only two are Catholic $(0.3 \%)$, though Catholics are about $20 \%$ of its total population.

35 The situation has slightly improved since 1990. The first Catholic chairman of the Commune Committee was a woman in 1989. However, due to some mistakes (not concerned with religious factors) she and some other colleagues were sentenced to imprisonment for two years. She was not a devout Catholic. 
The role of Christians in Phung Khoang in the resistance struggle of Viet Minh against the French colonialists was almost not recognized. ${ }^{37}$ Today some villagers still consider their Christian neighbors as collaborators of colonial authorities, although in a hushed voice. Christians are still caught in a power struggle between the state and the Church at the village level. In many cases, the Christian peasants obey the parish priest more than the secretary of the Communist cell, and the local authorities are not pleased.

\section{Conclusion}

The postcolonial period was not an easy period for the Phung Khoang Christian village. The social-political factors from both the state and the Christian Church increase the gulf, on the one hand, between Christians and non-Christians, and between the parish and the local authorities, on the other. The gulf during the postcolonial period appeared to be wider than during the colonial. "If it is true that religion with its doctrines and rituals belongs to the most potent cultural forces - for better or worse - influencing people's values and subsequently their attitudes, convictions, and interactions" (Do and Valco 2018, 621), more political and academic attention should certainly be paid to this social and cultural phenomenon. (Bąk et al. 2019)

\section{References}

Bąk, Tadeusz, Maria Kardis, Michal Valco, Aydar M. Kalimullin and Alexander A. Galushkin. 2019. A philosophical-sociological diagnosis of youth subcultures in the context of social changes. XLinguae 12, no. 2:163-185. https:// doi.org/10.18355/xl.2019.12.02.14

Buttinger, Joseph. 1958. The smaller dragon: A Political History of Vietnam. New York: Preager Publisher.

Do, Thi Kim Hoa, and Michal Valco. 2018. The philosophy of human rights and the "political man«: Engaging the intellectual legacy of Ho Chi Minh in a technological era. XLinguae 11, no. 2:608-624. https://doi.org/10.18355/ xl.2018.11.02.49

Hammer, Ellen J. 1959. The Struggle for Indochina. Stanford: Stanford University Press.

Hoang, Van Chi. 1964. From Colonialism to Communism: A Case History of North Vietnam. New York: Preager Publishing House.
Lich su cach mang xa Trung Van 1945 - 1995 [Revolutionary History of Trung Van]. 2005. Hanoi: Nha xuat ban Chinh tri Quoc gia.

Moise, Edwin E. 1983. Land reform in China and North Vietnam: Consolidating the Revolution at the Village Level. Chapel Hill-London: The University of North Carolina Press.

Ngo, Cao Lang. 1975. Lich trieu tap ky [A General Royal Chronicle]. Vol. 2. Trans. by Hoa Bang. Hanoi: Publishing House Khoa hoc Xa hoi.

Ngo, Thi Loan. 2006. Hop tac xa Thong Nhat, Bao cao tong hop ket qua san xuat kinh doanh dich vu khoa 4 năm 2002-2005, nguoi tong hop Ngo Thi Loan, ngày 24/3/2006 [Thong Nhat Cooperative, General Report on Production and Service Activities from 2002 to 2005, written by Ngo Thi Loan, dated March 24, 2006].

Nguyen, Hong. 1959. Lich su truyen giao o Viet Nam [History of Christian mission in Vietnam]. Zv. 1. Saigon: Publishing House Hien tai.

37 The role of Catholics in Phung Khoang in the First and the Second Indochina Wars, as well as the consequences of the land reform, are omitted from the monograph on the history of the village. 
Nguyen, Quang Hung. 2006. Phong van ong Tran Quoc Cuong, Chu nhiem Hop tac xa Thong Nhat, ngày $16 / 8 /, 15 / 10 / 2005$ va $30 / 5 / 2006$ (Interviews by author with Mr. Tran Quoc Cuong, Chairman of Thong Nhat Cooperative, a Catholic, dated August 16, October 15, 2005 and Mai 30, 2006.

- - - 2008a. Vietnam today: The State and the Catholic Church at Central and Local levels. Religious Studies Review 2, no. 4:13-25.

- - - 2008b. Phong van ong Nguyen Van Suong, lang Phung Khoang, 18/3/2008, 26/3/2008 (Interviews by the author with Mr. Nguyen Van Suong, village Phung Khoang, dated March 18 and 26, 2008); Phong van ong Nguyen Van Thanh, Trung Van village, ngày 31/5/2008 (Interview by the author with Mr. Nguyen Van Thanh, dated Mai 31, 2008).
Nguyen, Thi Minh Quy. 2006. Mot so bien dong ve doi song ton giao va van hoa xa hoi cua cong dong giao dan lang Phung Khoang Ha Noi hien nay [Some changes in cultural-religious life in Catholic village Phung Khoang today], KL-CN. 2115, Hanoi.

Reports of Cooperative Thong Nhat (Phung Khoang). Hop tac xa Thong Nhat, Bao cao tinh hinh hoat dong cua Hop tac xa Thong Nhat tu 200030/9/2005, so 145/BC-HTX (Thong Nhat Cooperative, Report on Activities from 2000-to September 30, 2005, No. 145-BC-HTX, dated October 10, 2005).

Truong, Ba Can. 1996. Cong giao Viet Nam sau qua trinh 50 nam (1945-1995) [50 Years of Catholicism in Vietnam (1945-1995)]. Ho Chi Minh City. 